\title{
O LEGISLADOR E A FORMAÇÃO DO ESPÍRITO PÚBLICO NO REPUBLICANISMO DE ROUSSEAU
}

\author{
Vital Francisco Celestino Alves ${ }^{1}$
}

\begin{abstract}
Resumo: Ao encerrar a sua explicação concernente à noção de Lei, no capítulo VI do segundo livro do Contrato social, Jean-Jacques Rousseau apresenta algumas inquietaçóes referentes à capacidade de uma população prematura elaborar um sistema de legislação. Tais inquietaçóes conduzem o pensador genebrino a preconizar a necessidade de uma figura polêmica e excepcional, na engrenagem política republicana: o legislador. Considerando a excepcionalidade dessa figura, o presente artigo sustentará a hipótese de que, mais do que alguém hábil em formular um conjunto de leis para um determinado povo, a função republicana primordial de um legislador é a de contribuir para engendrar um espírito público em cada cidadáo pertencente à república. A hipótese aventada será defendida a partir de três objetivos: primeiro, examinar-se-âo as razôes pelas quais Rousseau julga ser necessário um legislador na ordenação republicana; segundo, analisar-se-á por que a construção de um espírito público pelo legislador pode ser considerada uma funçấo republicana; terceiro, perscrutar-se-ão quais são as condiçôes necessárias para um povo receber uma boa legislação.
\end{abstract}

Palavras-chave: Legislador. Espírito público. Republicanismo. Rousseau.

\section{INTRODUÇÃO: UMA FIGURA EXCEPCIONAL}

A reflexão política deflagrada por Rousseau, no Contrato social, evidencia uma delimitação da soberania como "o poder de legislar", e a legitimidade dessa soberania encontra-se alicerçada na exigência de que ela seja desempenhada pelo povo. O posicionamento adotado pelo filósofo genebrino repousa uniformemente na ideia do soberano como "um corpo moral e coletivo" constituído de cidadãos que compartilham a mesma compreensão de

\footnotetext{
${ }^{1}$ Doutor em Filosofia, Universidade Federal de Goiás (UFG), Goiânia, GO - Brasil. (D) https://orcid. org/0000-0001-9072-5002 E-mail: vitalalves1@gmail.com
}

http://doi.org/10.1590/0101-3173.2020.v43n2.17.p301

\section{(i)}


bem comum. Rousseau delineia essa posição no capítulo VI do Livro primeiro do Contrato, no qual oferece aos seus leitores a sua noçáo de "pacto social"2.

Ao aderirem ao pacto social, os associados passam, por um lado, a ser designados como "cidadãos", uma vez que se tornam membros da autoridade soberana, e, por outro lado, são identificados como "súditos", quando se subordinam às leis da ordenação republicana. A anuência ao pacto de associação estabelece, em seguida, que os cidadáos passem a se guiar pela "vontade geral", pois a preservação da liberdade política e civil ${ }^{3}$ depreende a prevalência da vontade aludida. Isso significa que, para salvaguardar a liberdade de possíveis ameaças, oriundas de vontades arbitrárias 4 , é crucial que os cidadãos conduzam suas decisões nas assembleias ${ }^{5}$, tendo em vista a vontade geral. Furtar-se dessas ameaças pressupóe que os atos que pleiteiem um cumprimento de obrigaçóes pelos cidadáos abranjam igualmente todos os cidadãos, tenham amparo nas leis e que elas sejam elaboradas pelos cidadãos, ou seja, o povo soberano tem a incumbência de deliberar acerca de quais leis basilares devem preponderar na ordem política.

A noção de "lei" se inscreve assim como um recurso conceitual decisivo, para que possamos entender o nexo entre "a teoria da soberania e a

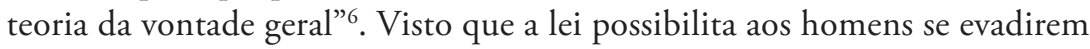

\footnotetext{
${ }^{2} \mathrm{O}$ capítulo mencionado deve ser lido como uma parte de fundamental importância no Contrato, na medida em que servirá de eixo para o desenvolvimento da investigação política rousseauniana, a qual testemunharemos na sequência da obra. Rousseau, convém assinalar, inaugura o capítulo partindo de uma hipótese concernente aos empecilhos que prejudicariam a preservação do "homem no estado de natureza". Tais empecilhos, como se pode constatar no Segundo Discurso, estâo relacionados a fenômenos da natureza (tempestades, desastres naturais, cataclismos etc.), fenômenos que, apesar de, fatalmente comprometeriam a sobrevivência do homem. São justamente as dificuldades no estado de natureza que exigem uma mudança de vida do homem - daí surge a necessidade de um pacto social. Cabe esclarecer, todavia, que se conjectura que o pacto, na perspectiva do escritor genebrino, longe de se apresentar como um fator histórico, é explicitado como uma hipótese explicativa.

${ }^{3}$ Em nossa interpretação, a "liberdade política" se refere à liberdade do cidadão (participante ativo da vida pública), enquanto a "liberdade civil" diz respeito à liberdade do súdito (aquele que obedece a lei). Para uma compreensão ampla sobre a dualidade do homem: cidadão e súdito na teoria política rousseauniana, sugere-se a seguinte referência bibliográfica: Men \& citizens - a study of Rousseau's social theory, de Judith Shklar (1985).

${ }^{4}$ De acordo com Rousseau, as facções são vistas como um dos fenômenos que podem assumir vontades dessa natureza e afetarem diretamente a prevalência da vontade geral.

${ }^{5} \mathrm{O}$ autor genebrino defende que elas sejam fixas e periódicas e tratem de assuntos gerais. Nas assembleias, os cidadãos terão como objetivo identificar a vontade geral nas questôes públicas apresentadas para a apreciação.

${ }^{6}$ Céline Spector (2015) no livro Les paradoxes de l'autonomie démocratique perscruta o encadeamento entre essas duas teorias.
} 
da dependência de outros homens, isto é, de uma vontade discricionária, a lei opera fundamentalmente como um instrumento que protege um homem de uma vontade que náo seja a sua ou de um capricho de outro homem. A premissa de obediência à lei resguarda a liberdade do homem, pois ser livre se refere a obedecer à própria vontade ${ }^{7}$. Essa premissa não apenas opera como protetora da liberdade, mas, paralelamente, assevera a igualdade entre os homens.

Julgando ser provável a correspondência entre as teorias supracitadas e considerando a incapacidade dos homens ${ }^{8}$ de reconhecerem a sua vontade (geral) enquanto cidadáos e membros do soberano, Rousseau justifica, no final do capítulo VI do Livro primeiro do Contrato, a indispensabilidade de se evocar uma "figura excepcional" e que exercerá uma função decisiva na república. Trata-se da figura do "Legislador". Lemos, no Manuscrito de Genebra e, mais tarde no Contrato social, uma profícua teoria a respeito do Legislador. A envergadura política do Legislador o insere em uma extensa tradição ${ }^{10}$ e, amiúde, o situa em posiçôes estratégicas nas mais diversas doutrinas políticas. O legislador, no republicanismo de Rousseau, apresenta uma série de peculiaridades e sua presença suscita estupefação ou desencoraja a maior parte dos intérpretes ${ }^{11} \mathrm{da}$ filosofia rousseauísta, que tradicionalmente o veem como uma personagem teórica obscura e ambígua ${ }^{12}$.

Em oposição a essa interpretação convencional - a qual avaliamos como precipitada -, a análise e a reflexão que serão expostas assumirão o compromisso de apresentar uma interpretação que defenderá a hipótese de que o legislador tem como missão fulcral contribuir com "a formação do espírito público" nos cidadãos da república. Ao assumir essa interpretação, concomitantemente, se buscará dissipar as habituais obscuridades e ambiguidades que gravitam em torno da figura do legislador. Para tanto, daremos ênfase a como surge

7 Convém dizer que a vontade do cidadão é a vontade geral. Ao se orientar pela vontade geral, o cidadão estará obedecendo a própria vontade. A lei enuncia a vontade geral, portanto, a obediência à lei no arranjo teórico de Rousseau pode ser compreendida como um exercício da liberdade.

8 Ao analisarmos a "necessidade de um Legislador" (no tópico seguinte), serão deslindados os argumentos empregados pelo cidadão de Genebra que os orientam a afirmar a existência de uma suposta "incapacidade" dos homens de tomarem algumas importantes decisóes após a consolidação do "pacto".

9 Demonstraremos adiante, em nossa análise, por que Rousseau considera o "legislador" uma figura excepcional.

${ }^{10}$ Que comporta pensadores como Platão e Maquiavel, por exemplo.

${ }^{11}$ Podemos tomar as interpretaçôes de Vaughan (1915), como espécime.

${ }^{12}$ Nesse ponto, compartilhamos a visão de Raymon Polin (1964). 
a "necessidade de um Legislador", analisaremos as singularidades da sua "função republicana" e examinaremos quais são "as condiçôes para um povo receber uma boa legislação". Almeja-se, desse modo, fornecer uma relevante contribuição para a realização de uma leitura republicana acerca do ofício magistral do legislador.

\section{A NECESSIDADE DE UM LEGISLADOR}

Rousseau, no Contrato social, define a "república" como um Estado regido por leis, independentemente da forma de governo. Essa ordenação política possui legitimidade e nela há prevalência do interesse público sobre o interesse privado. Verifica-se, no pensamento rousseauísta, que os membros associados ao corpo político serão responsáveis por regularizarem as condições que guiarão a sociedade.

Entretanto, concomitantemente a essa definição, o autor genebrino revela, também, dúvidas sobre a capacidade do povo em regulamentar tais condiçóes sobre qual instrumento melhor expressará sua vontade e como procederá, em situações prementes. Em síntese, indaga-se: de que maneira uma populaçáo incipiente e ainda destituída da capacidade de discernimento - uma multidão cega -, e que amiúde desconhece a sua vontade ${ }^{13}$ pela inaptidão de identificar o que lhe condiz, poderá realizar uma tarefa tão complexa e árdua como a elaboração de um sistema de legislação? Ambicionando investigar essa questáo, o autor do Contrato nos remete a alguns dos axiomas que formam seu edifício teórico, tais como: o povo sempre deseja o seu próprio bem, mas nem sempre consegue reconhecê-lo, ou a vontade geral é sempre certa, todavia, o arbítrio que a conduz frequentemente carece de esclarecimento. A partir dessas inquietaçôes, Rousseau (1964, p. 380) expóe a célebre afirmação:

É preciso fazê-la ver os objetos tais como são, algumas vezes tais como eles devem parecer-lhe, mostrar-lhe o caminho certo que procura, defendê-la da sedução das vontades particulares, aproximar a seus olhos os lugares e os tempos, pôr em balanço a tentação das vantagens presentes e sensíveis com o perigo dos males distantes e ocultos. Os particulares discernem o bem que rejeitam; o público quer o bem que náo discerne. Todos necessitam, igualmente, de guias. A uns é preciso obrigar a conformar a vontade à razão, e ao outro, ensinar a conhecer o que quer. Então, das luzes públicas resulta a união do entendimento e da vontade no corpo social, daí o

\footnotetext{
${ }^{13}$ Que, além de ser sua, diz respeito ao bem público.
} 
perfeito concurso das partes e, enfim, a maior força do todo. Eis donde nasce a necessidade de um Legislador. ${ }^{14}$

Nessa afirmação, nota-se a origem da necessidade de um legislador. Ele desempenhará uma função decisiva, na república. Porém, antes de compreendermos em que consiste sua função, é imprescindível entender quem é essa figura e suas principais características. Rousseau abre o capítulo VII do segundo livro do Contrato social realçando que, para se encontrar as normas de sociedade mais apropriadas aos organismos políticos, seria fundamental a presença de uma inteligência superior ${ }^{15}$. Alguém capaz de interpretar as paixôes humanas e eximir-se delas, que não possua qualquer tipo de vínculo ou envolvimento com a nossa natureza, mas que, ao mesmo tempo, seja suficientemente hábil para compreendê-la em sua intimidade. Um homem ao qual a felicidade não esteja inerente à do povo, no entanto, apesar disso, tenha a disposição de se empregar na tarefa de produzir um sistema de legislação, sem almejar um prestígio imediato. Rousseau (1964, p. 381) polemiza ainda, com sua peculiar estilística: "seriam necessários deuses para dar leis aos homens". ${ }^{16}$

Com o objetivo de explicitar as dificuldades de se encontrar um grande legislador, Rousseau traça inicialmente uma comparação entre essa figura e

\footnotetext{
${ }^{14}$ Il faut lui faire voir les objets tels qu'ils sont, quelquefois tels qu'ils doivent lui paroitre, lui montrer le bon chemin qu'elle cherche, la garantir de la séduction des volontés particulieres, rapprocher à ses yeux les lieux et les terms, balancer l'attrait des avantajes présens et sensibles, par le danger des maux éloignés et cachés. Les particuliers voyent le bien qu’ils rejettent: le public veut le bien qu'il ne voit pas. Tous ont également besoin de guides: Il faut obliger les uns à conformer leurs volontés à leur raison; il faut apprendre à l'autre à connoitre ce qu'il veut. Alors des lumieres publiques resultes l'union de l'entendement et de la volonté dans le corps social, de-là l'exact concours des parties, et enfin la plus grande force du tout. Voilà d'où naît la necessite d'un Législateur. (CS, II, VI. OCR3, tradução nossa).

15 Apesar de a retórica rousseauísta parecer se referir a alguém superdotado intelectualmente, como destaca Lourival Gomes Machado, em nota de rodapé da edição brasileira (Os Pensadores), as idiossincrasias extraordinárias que Rousseau confere ao legislador tratam mais do conteúdo e propósito de seu empreendimento do que propriamente das particularidades que lhe são "naturais". Evidentemente, elas não podem ser negligenciadas.

${ }^{16}$ Il faudroit des Dieux pour donner des loix aux hommes. (CS, II, VII. OCR3, tradução nossa). Convém ressalvar que, na nossa interpretação, a linguagem utilizada por Rousseau, marcada por alusôes aos deuses, tem como finalidade grifar o cunho frequentemente prodigioso da vida coletiva. Nesse sentido, o legislador pode ser considerado um homem dotado de uma consciência apurada para entender as necessidades comuns de um povo. Os trabalhos de Roger Masters (1968) e Raymond Polin (1964) dão suporte a essa nossa leitura. Resgataremos essa ideia, mais adiante.
} 
a do estadista, retomando Platão ${ }^{17}$, que revela, no Político, o quão raro é um verdadeiro estadista e os desafios de se encontrá-lo. Jean-Jacques assinala que, se é difícil encontrar um estadista admirável, mais ainda é reconhecer um legislador excepcional. Enquanto o estadista tem a incumbência de encaixar as peças do aparato político e conferir-lhe a dinâmica, isto é, executar a função de um trabalhador operacional, o legislador é o gênio ${ }^{18}$ inventivo da engrenagem republicana - no vocabulário rousseauniano: "o mecânico que inventa a máquina” (ROUSSEAU, 1964, p. 381) ${ }^{19}$. A fim de ratificar seu ponto de vista, o genebrino traz à tona as palavras usadas por Montesquieu ${ }^{20}$, no capítulo I de suas Consideraçôes sobre as causas da grandeza dos romanos e da sua decadência (2005), onde se lê que as sociedades se originam mediante a presença dos chefes das repúblicas, são eles que engendram a instituição e, posteriormente, a mesma fabrica os estadistas.

Salinas Fortes (1976) nos esclarece que cabe ao legislador dar à luz a máquina artificial do Estado, uma vez que ele tem a incumbência de sugerir leis. O intérprete, todavia, postula uma problematização de extrema pertinácia, quando equaciona, em outros termos, a seguinte questão: o surgimento do legislador, na conjuntura política, não contradiz a soberania do povo, firmada precedentemente ${ }^{21}$ ? Afinal, se remontarmos ao capítulo VI do Livro II do Contrato social, pode-se atestar que o poder de elaborar as leis compete apenas

\footnotetext{
${ }^{17}$ Embora Rousseau cite Platão - que traça o perfil clássico do legislador, nas Leis e no Político - , cumpre frisar, com base nos estudos de Roger Masters (1968), as significativas diferenças entre os legisladores apresentados por ambos os filósofos. O intérprete em questão defende que a concepção platônica equivale à de um legislador político-estadista, enquanto a rousseauniana se inscreve como uma noção que se assemelha a uma espécie de pedagogo político. Para Masters, Rousseau desconstrói a personificação clássica do legislador, ao aludir à figura de um legislador na qual se nota uma ênfase no caráter criativo da razáo humana. O genebrino fundamenta sua concepção no pressuposto de que a obediência pode ser deslindada a partir da liberdade e da vontade. O republicanismo de Rousseau confere primazia ao consentimento voluntário popular das leis, amparado na vontade geral. E as leis que não têm esse consentimento, diferentemente da opiniáo de Platão, não podem ser consideradas leis. Visto que, em Rousseau o conhecimento no terreno da política não é preceito exclusivo da melhor constituição, o cidadáo de Genebra isenta o legislador da responsabilidade de demarcar aquele que seria o melhor regime e entende sua função como uma ciência da prudência, a qual lhe possibilitará compreender as especificidades do povo ao qual ele se direciona.
}

${ }^{18}$ Para ver mais sobre a concepção de gênio criativo em Rousseau, sugerimos a leitura da obra Rousseau ou la conscience sociale des lumières, de Éliane Martin-Haag (2009).

${ }^{19}$ Le méchanicien qui invente la machine. (CS, II, VII. OCR3, tradução nossa).

${ }^{20}$ É interessante lembrar também que, no livro II d'O Espirito das leis, o pensador de Bordeaux expressa sua admiração à genialidade de grandes legisladores que foram capazes de educar os povos, dando leis favoráveis à estabilidade e à grandeza.

${ }^{21}$ Isto é, do pacto de associação. 
ao povo reunido, tendo em vista que as leis se configuram em atos da vontade geral. Salinas, embasado nos comentários de Vaughan (1915), acrescenta ainda que, na perspectiva rousseauísta, as leis se depreendem em uma condição da associação civil na qual o povo, sujeito às leis, também seja o seu autor.

O escritor de Rousseau: da teoria à prática explica que, em contextos nos quais o povo é incapaz de realizar o que o bem público ${ }^{22}$ exige, ele não terá, indubitavelmente, competência para formular um conjunto de leis. Dessa incapacidade emana a necessidade da primordial figura mediadora do legislador. Contudo, mesmo que o direito de formular as leis diga respeito à alçada do povo, nessa conjuntura, o direito por si só não basta; o poder de realizaçâo do ofício torna-se decisivo e é justamente desse poder, devido às suas limitaçóes, que o povo carece.

Salinas registra que a contradição só existe aparentemente. Ele justifica que a posição de Rousseau se baseia numa alteraçấo de perspectiva: "o povo real" se distingue do "povo ideal", que se associa no pacto fundamental ${ }^{23}$. Ora, entre o povo e a multidão cega há um oceano a ser navegado sob a ingerência do legislador ${ }^{24}$. Em relação ao direito, lembremos que apenas ao povo convém fixar as condições da associação, da mesma forma, o direito avaliza que a vontade geral não pode ser representada por ninguém, além do próprio povo. Entretanto, nessa estrita situação, o povo ainda é uma massa destituída da capacidade de discernimento, pois uma massa constituída de indivíduos pautados unicamente pelos seus interesses mais instantâneos, portanto, inábil na fabricação do corpo político, logo, precisa de alguém que a auxilie a identificar a vontade geral, isto é: os indivíduos carecem de um guia.

Vale rememorar que o pacto é um "instante" e, em decorrência disso, não consegue transformar instantaneamente aqueles seres que contratam em verdadeiros cidadãos. Julgamos, a partir dessa recordação e considerando a interpretação de Milton Meira, em Entre a escala e o programa, que o legislador

\footnotetext{
${ }^{22}$ Por exemplo, nos momentos em que precisará identificar a vontade geral em uma questâo pública apresentada em uma assembleia.

${ }^{23}$ Em nosso entendimento, não se trata simplesmente de distinguir um "povo real" de um "povo ideal", mas sim de uma mudança do indivíduo - perfeito e solitário. Além disso, como bem identificou Milton Meira (1984) - com quem estamos de acordo -, dentro do Contrato social, há uma mudança no nível do discurso, isto é, uma passagem do "dever ser" para um programa de ação, na medida em que Rousseau demonstra preocupaçóes com situações reais.

${ }^{24}$ Cabe registrar que invocar a necessidade do legislador como forma de guiar a travessia desse "oceano" que separa o "povo" da "multidão cega" não pode ser tomado como um expediente de verticalização da legitimidade do poder, como mostraremos a partir do parágrafo seguinte.
} 
deve ser compreendido como uma figura que transita entre o ideal e o factual. Ele representa essa transição - do dever ser à proposta de ação ${ }^{25}$. Sua tarefa sucede da necessidade de desenvolver as capacidades necessárias à vida em comum que ainda carece naqueles seres primitivos que criam o Estado civil. Cumpre também afirmar que o legislador não tem poder de soberania ${ }^{26}$, pois, em sua estrita acepção, a soberania pertence ao povo.

Ademais, a função do legislador também se distingue tanto da do governo quanto da do magistrado, que têm como atribuição, respectivamente, a aplicabilidade das leis em circunstâncias particulares ou por intermédio de decretos. Observa-se, na filosofia de Rousseau, que a figura do legislador atua como suporte para a aquiescência das leis e serve igualmente como espinha dorsal de sustentação da soberania e do governo. Em se tratando da lei, que Cassirer (1932) concebe como a pedra angular do sistema político rousseauísta, é interessante ressaltar que o legislador recomenda aquelas que avalia serem convenientes a um povo específico, mas quem delibera e as sanciona é o povo.

\section{A FUNÇÃo REPUbliCANA DO LEGISLAdOR}

Partindo da ilustraçáo do legislador como o mecânico inventivo da república, dotado de notável talento para edificar a máquina política, Rousseau advoga que quem se atreve a assentar as bases ou propriamente fundar a instituiçáo de um povo deve ter a capacidade de transformar a natureza humana. No entanto, em que consiste essa mudança de natureza à qual Rousseau se refere? Deve-se lembrar de que a perspectiva política rousseauniana concebe cada indivíduo como um todo perfeito e solitário e que o seu ingresso no corpo político o inscreve como partícipe de um todo maior. É precisamente nesse ponto que o legislador começa a efetuar seu encargo, instalando uma vicissitude na natureza humana, a promover uma transição da constituição plena de cada indivíduo solitário à uma vida coletiva.

\footnotetext{
${ }^{25} \mathrm{Se}$, por um lado, a figura do legislador faz bastante sentido, quando trata dos homens como são e deixa clara a necessidade de formá-los para a vida coletiva, por outro, a leitura do texto de Milton Meira introduz indagaçóes a respeito de leituras desacertadas que veem o Contrato social exclusivamente como um programa político, ao invés de uma escala de referência que nos fornece munição para julgar as instituiçóes políticas.

${ }^{26}$ Portanto, não se pode afirmar que a figura do legislador representa um "desvio" no projeto horizontal do Contrato. E, tendo em vista que, nessa conjuntura, o povo ainda é considerado uma "massa destituída da capacidade de discernimento", a necessidade da existência de um legislador surge para que se oriente "a vontade à razão", isto é, urge consubstanciar, no corpo político, o entendimento e a vontade.
} 
O legislador suscita a socializaçáa ${ }^{27}$ dos indivíduos e tem a destreza indispensável para depreender a necessidade crucial desse encadeamento. Por meio do seu talento e disposição, ele auxiliará os indivíduos nessa passagem. A complexa tarefa demanda que os indivíduos substituam seus ímpetos naturais desmedidos por parâmetros de conduta que dizem respeito a todos e sejam eficientes em prepará-los para a vida republicana. Rousseau argumenta que a gradativa dissipação dos impulsos naturais contribui diretamente para a fortificação dos princípios coletivos e a consolidação e durabilidade da instituição política nascente. Quanto mais cada indivíduo se reconhecer como cidadão parte de um todo maior e igual aos seus concidadãos, mais próxima da perfeição estará a legislação.

Em face do que significa essa transformação da natureza humana, Céline Spector (2015) imputa ao legislador duas funçóes: uma, cognitiva, na medida em que ele auxilia o povo a identificar o bem público, e outra, afetiva, correlacionada à desnaturalização que ele fomenta no homem. A intérprete recorda que o legislador tem por mister fundar o espírito social ${ }^{28}$ que deverá reger a república. Para imprimir durabilidade à instituição política, caberá a ele esforçar-se no desempenho de sua função e balizá-la nos costumes e na opiniâo pública ${ }^{29}$. O legislador se ocupará de convencer o povo da importância benfazeja das leis que ele propóe e de submeter a natureza dos indivíduos a uma metamorfose, quer dizer, a transformação do homem em cidadão. Rousseau tenciona que o legislador viabilize uma desnaturalização do homem,

${ }^{27}$ Ora, se, no Segundo discurso, o advento da propriedade marca o momento da socialização dos indivíduos, no Contrato, ela é suscitada pelo legislador, posto que sua função consiste justamente em "transformar" indivíduos solitários em membros de um corpo coletivo. O desempenho da tarefa republicana do legislador fomenta o processo de socialização dos indivíduos, visto que ela contribui frontalmente para a produção de um "espírito público" em cada cidadão membro da ordem republicana.

${ }^{28}$ Isso significa, em nossa percepção, que mais do que recomendar leis, a função do legislador é, sobretudo, a de contribuir para a formação de cidadáos dotados de "espírito público". A leitura oferecida por Céline Spector, assim como uma próxima à dela, apresentada por Derathé, no artigo L'homme selon Rousseau, nos abre esse horizonte interpretativo.

${ }^{29}$ Ao investigar a simetria entre o escritor político e o legislador e defender a hipótese de que ambos se colocam como inventores que desempenham uma função praticamente acima das forças humanas, Milton Meira do Nascimento (1997) defende que, tendo em vista que a opiniáo pública se esquiva de todo tipo de pressáo, independentemente de elas se originarem das leis ou das autoridades, intervir sobre ela se configura em um dos encargos mais árduos e seus efeitos recorrentemente são fortuitos. E sinaliza: "a ação do legislador sobre a opinião pública será sempre no sentido de preservar o julgamento do público para que ele acerte na escolha do bem público. Essa tarefa será a de não deixá-lo perder a memória dos tempos da fundaçấo. O que importa aqui também é que o corpo político não se desfigure. A educação pública, nesse contexto, será um trabalho de preservação do espírito de fundação, em que o povo se apresenta com uma vida artificial, resultante do pacto de associaçáo. O procedimento do educador do Emílio é aqui imitado pelo legislador". 
como escreve no Manuscrito de Genebra, reiterada no Contrato, para fazer com que cada individuo, perfeito e solitário passe a se compreender como parte de um todo maior.

O organismo político deve perpetrar uma íntima mutação da natureza humana: transmutar a natureza dos interesses dos indivíduos, conferindo novos status às suas paixóes. Por conta disso, pode-se admitir que, na visão do genebrino, a edificação do corpo político é tida como uma transformação. Como ele mesmo escreve, no Emílio, o mecanismo político deve produzir uma nova humanidade, na qual os sentimentos naturais sejam substituídos por sentimentos cívicos. E cumprirá à figura do legislador se esforçar para ensejar essa mudança de perspectiva.

Para Salinas Fortes (1976), a transformação da natureza humana exposta por Rousseau encontra-se diretamente ligada à ideia de que o legislador deverá agir sobre os associados envolvidos no pacto social, com o objetivo de mudar o princípio que usualmente orienta suas açóes, a saber: deve impossibilitar que o amor próprio se sobressaia efetivamente como a paixão individual preponderante. Se não existe república sem cidadãos, cumpre ao legislador contribuir para formar cidadãos; dito de outra forma, deve converter o homem natural - perfeito e solitário - em uma parcela da totalidade social. Partindo do pressuposto de que Rousseau compreende os homens como eles de fato o são, a necessidade de estruturar a sociedade cimentada na prevalência da vontade geral requer precipuamente a presença do legislador, porque a fundação de uma ordem política justa reclama que os membros pactuantes sejam conduzidos por um homem extraordinário, o qual indique os caminhos a serem percorridos e assole, mediante uma abordagem pedagógica, as predisposiçóes presentes na natureza dos indivíduos que possam impedir a consolidação da unidade do tecido social.

Dessa habilidade de transformar a natureza humana, entende-se claramente por que, para Rousseau, o legislador é um homem extraordinário. Deve-se observar que esse atributo condiz ao seu talento e não à função que ele desempenha. Convém esclarecer ainda que tal figura não tem poder de magistratura, nem tampouco de soberania ${ }^{30}$. O genebrino nos alerta para o risco de os legisladores, em sua percepção, aqueles legisladores que acumulam esses

${ }^{30}$ Como temos defendido, o legislador indica leis, mas sua principal função é o de trabalhar para formar cidadãos depositários de espírito público. 
poderes, ${ }^{31}$ ao se tornarem governantes, tenderem a ser tiranos ${ }^{32}$. Justificando sua posição, o autor do Contrato afirma que quem governa os homens não deve legislar, e o contrário também não deve acontecer, pois a aglutinação de poderes geraria leis fundamentadas em paixóes individuais que reproduziriam injustiças; com efeito, seriam deletérias à integridade da república. Nos termos de Rousseau (1964, p. 383):

Aquele que redige as leis, não tem nem deve ter nenhum direito legislativo. $\mathrm{O}$ próprio povo não poderia, se o desejasse, despojar-se desse direito incomunicável, porque, segundo o pacto fundamental, só a vontade geral obriga os particulares e só podemos estar certos de que uma vontade particular é conforme a vontade geral depois de submetê-la ao sufrágio livre do povo. ${ }^{33}$

Constata-se assim o caráter específico da ação empregada pelo legislador e a sua confluência à vontade geral, uma vez que tem uma capacidade magistral de recomendar leis em consonância com o bem comum do povo. Admitese, em conformidade, que a realização do trabalho do legislador se evidencia por aspectos aparentemente assimétricos, a saber, uma tarefa sobre-humana digna dos deuses que é operada por uma autoridade destituída de poder. Com isso, Rousseau parece abrir margem para interpretarmos o legislador como sendo uma figura de origem distinta ${ }^{34}$ da nação, à qual ele apresentará um sistema de legislação, a partir das especificidades do povo, e alguém que, após acompanhar a aplicação do sistema, naturalmente se afastará da sua obra, como

\footnotetext{
${ }^{31}$ Legislativo e executivo.

${ }^{32}$ Polin (1964) nos lembra de que a função do legislador em Rousseau náo é a de fundar um Estado e governar os homens, tampouco de ser por um tempo legislador e soberano, como no caso do fundador do Estado, nos Discursos de Maquiavel. Sua função é, como temos sustentado, a de transformar a natureza dos homens, fazendo-os cidadãos apropriados à república. O legislador atua fornecendo um projeto político para um povo, sugerindo leis adequadas para se instituir um Estado e contribuir na formação dos cidadãos. Não obstante, o próprio Rousseau deixa nítido que o legislador não tem lugar na constituiçẫo que ele projeta. Em suma, ele propóe as leis, escreve-as, direciona conselhos políticos ao povo, todavia, não tem nenhum direito legislativo.

${ }^{33}$ Celui qui redige les loix n'a donc ou ne doit avoir aucun droit législatif, et le peuple même ne peut, quand il le voudroit, se dépouiller de ce droit incommunicable; parce que selon le pacte fondamental il n'y a que la volonté générale qui oblige les particuliers, et qu'on ne peut jamais s'assurer qu'une volonté particuliere est conforme à la volonté générale, qu'après l'avoir soumise aux suffrages libres du peuple. (CS, III, III. OCR3, tradução nossa).

${ }^{34}$ Embora Rousseau não explicite que o legislador deve ser alguém de fora do povo que ofereça leis. $\mathrm{Na}$ nossa interpretação, ao versar que, na Antiguidade, era comum requisitar legisladores estrangeiros e, ao se valer de referências como Licurgo e Moisés, o cidadão de Genebra nos possibilita realizar esse tipo de leitura.
} 
fez o próprio autor, ao apresentar projetos constitucionais para a Córsega e a Polônia ${ }^{35}$.

Outra dificuldade na realização do ofício do legislador destacada por Rousseau refere-se a uma característica intrincada que deve marcar o cumprimento da faina desse homem excepcional: a linguagem. O filósofo defende que os homens dotados de sabedoria que pretendem falar ao povo por meio da linguagem deste, ao invés da sua própria, dificilmente conseguiriam ser entendidos, posto que existem demasiados tipos de noçôes que não podem ser vertidas para a linguagem popular. Isso acontece porque a generalidade das opinióes e as metas a serem alcançadas, em longo prazo, costumam se apresentar como algo que parece remoto à realidade do povo, também devido à ausência de razoabilidade dos indivíduos em perceberem as serventias de um projeto legislativo que transcenda os seus interesses pessoais instantâneos, mas que lhe poderão trazer benefícios assegurados pelas leis.

Devemos sublinhar que o povo ao qual Rousseau está aludindo é um povo prematuro e, para que ele entenda os princípios políticos e assimile as normas que orientarão a república, seria fundamental que "os homens fossem antes das leis o que deveriam tornar-se depois delas" (ROUSSEAU, 1964, p. 383). ${ }^{36}$ Em outras palavras, o legislador, por ter a perspicácia de compreender os desígnios dessa sociedade rudimentar, trabalhará pedagogicamente ${ }^{37}$

\footnotetext{
${ }^{35}$ Devemos, entretanto, observar que a peculiaridade do trabalho realizado por Rousseau juntamente aos corsos e aos poloneses não condiz plenamente com o retrato do legislador descrito no Contrato. Provavelmente, em funçâo disso, foi que Salinas Fortes optou por utilizar a expressão "Legislador conselheiro", a fim de designar o seu procedimento, posto que se refere a alguém que, externamente, apresenta recomendaçôes que os povos deverâo apreciar, e, a partir daí, deferir ou indeferir, visando a delinear suas leis e instituições. Logo, não se pode afirmar categoricamente que o cidadão de Genebra se afastou dos povos aos quais sugeriu projetos constitucionais, visto que ele não chegou nem mesmo a conviver com tais povos. Ver mais em Rousseau: da teoria à prática - Luís Roberto Salinas Fortes (1976).

${ }^{36}$ Les hommes fussent avant les loix ce qu'ils doivent devenir par elles. (CS, II, VII. OCR3. Tradução nossa).

${ }^{37} \mathrm{O}$ elemento pedagógico na atuação do legislador gerou algumas notáveis discussōes. M. Pierre Burgelin (1963) defende que o legislador é um pedagogo para os povos, um ser prodigioso, cuja funçáo consiste substancialmente em guiar os homens para o caminho da virtude. Polin (1964) destaca que - igualmente ao pedagogo do Emílio, fornecedor de uma educaçáo capaz de estimular a criança a se desenvolver por si mesma, com base na própria liberdade -, as leis recomendadas pelo legislador (que, na ordem republicana, também exerce uma funçáo pedagógica) aguçam a liberdade de cada cidadão na construção da unidade e na identificação da vontade geral. Logo, o legislador se vale de um artifício político semelhante ao do pedagogo, ao propor inserir os homens no campo das instituições e das leis que conferirão a eles a virtude necessária aos cidadãos. Milton Meira (1997), ao abordar a particularidade pedagógica do legislador, assinala que, embora a ação do educador do Emílio possa ser vista como complementar à ação do legislador, ao contrastá-las, atestaremos que
} 
para imprimir nos indivíduos a consciência e o discernimento necessário à manutenção do pacto social ${ }^{38}$. O sítio de atuação do legislador, bem como as especificidades do povo ao qual ele se dirige, dispensa-o do uso da força e do discurso racional, o que lhe exigirá buscar esteio em "[...] uma autoridade de outra ordem, que possa conduzir sem violência e persuadir sem convencer" (ROUSSEAU, 1964, p. 383). ${ }^{39}$ Grosso modo, o legislador terá que recorrer à "sabedoria dos deuses", de sorte a conseguir fazer com que o povo se sujeite ao arranjo legislativo e expresse anuência ao poder fundamental das leis na república, tendo liberdade para respeitar os princípios republicanos e conformando-se à ventura pública.

$\mathrm{O}$ escritor genebrino pondera que esse recurso utilizado pelo legislador comprova a sua sabedoria: uma singularidade inexistente nos homens comuns. À custa desse recurso é que ele define as resoluçóes mais favoráveis ao povo - o uso da linguagem divina provavelmente pode ser identificado como um artifício político passional, instrumento tal que é acionado por esse homem extraordinário para "persuadir sem convencer". Rousseau assinala que são

elas não são equivalentes. $\mathrm{Na}$ verdade, enquanto não é possível ao legislador partir do homem em estado de natureza, o que tornaria frívola sua tarefa de erigir o Estado, o educador do Emílio buscará propriamente salvaguardar o homem natural, ou seja, sua educação negativa remete à conservação de sua bondade natural.

${ }^{38}$ Salinas Fortes (1976) afirma que a função do legislador é estabelecer o bem comum, demarcando as condiçôes que os associados deverão considerar. Ele nos lembra, todavia, de que somente há corpo político quando existe uma verdadeira plêiade entre seus partícipes. Não há corpo político, desse modo, na ausência de cidadãos, que têm como virtude o amor à pátria e sấo capazes de se sacrificar em nome do bem público.

${ }^{39}$ À une autorité d'un autre ordre, qui puisse entraîner sans violence et persuader sans convaincre. (CS, II, VII. OCR3, tradução nossa). Quem inicialmente nos auxilia a compreender essa questáo é Céline Spector. Em sua interpretação, o beneplácito de povos prematuros, destituídos de instrução e do que é o seu próprio bem, conduz Rousseau a delimitar o intricado desafio de persuadir sem convencer. Nesse sentido, por um lado, o genebrino rejeita o uso opressivo do constrangimento pela força que cerceia a política à mera prática de dominação e, por outro, apresenta uma filosofia que não estabelece um processo de convicção pavimentado por um entendimento racional, ou seja, é preciso conferir ao povo outro elemento além da razão. Para tanto, o legislador deverá se servir de um elemento sagrado, a fim de persuadir o povo. A demanda por persuadir sem convencer imputada à figura do legislador nos possibilita simultaneamente refletir sobre as controversas relaçốes entre política e religião ou, como bem grifou Leo Straus (1984), o legislador é uma figura simbólica que enseja a inauguração do político, buscando como alicerce um ponto cego sobre o qual o pensador político deverá se basear. Retomando a leitura de Spector, vemos que a falta de discernimento do povo e sua incapacidade de reconhecer a vontade geral fazem com que surja uma exigência de declaração para atender a essa dupla demanda: esclarecer e declarar. Assim, o recurso da linguagem dos deuses também confere ao legislador que deseja persuadir a oportunidade de expor seus pontos de vista, o que nos faz crer em uma mistificação da figura do legislador, a qual se aproxima da necessidade de uma instrumentalizaçáo do elemento religioso, como defendeu Maquiavel. 
raros os homens com a capacidade de falar o linguajar dos deuses e, mais ainda, em fazer-se acreditar pelo povo por intermédio desse mecanismo. Sua argumentação adquire concisão, quando ele enuncia que a especificidade aludida sinaliza a grandeza da alma do legislador, entendida como "o verdadeiro milagre $^{40}$ que deverá autenticar sua missão” (ROUSSEAU, 1964, p. 384) ${ }^{41}$.

O cidadão de Genebra aponta que homens vulgares habitualmente usam das mais variadas artimanhas ${ }^{42}$ para incutir suas vontades e decretos discricionários a um povo, no entanto, estratégias como essas, por si só, mesmo sendo frágeis e estranhamente capazes de aglomerar por contingência certa quantidade de pessoas desatinadas, estarão fadadas a um vertiginoso declínio. Improvavelmente, elas serão capazes de erigir uma ordenação política sólida e duradoura como a obra que produzirá o excepcional legislador, o qual será objeto de encantamento, acima de tudo, por produzir instituições políticas resistentes e fomentar o espírito público nos cidadãos.

\section{As CONDIÇÓES PARA UM POVO RECEBER UMA BOA LEGISLAÇÃO}

Compreendidas as singularidades do legislador e sua função republicana, e, na mesma medida, considerando o esforço que empreendemos até aqui, em nossa ilustração, resta examinar, embora com celeridade, uma vez que nos aproximamos do desfecho desta reflexão, uma questão que o próprio Rousseau postula: que povo está preparado para receber uma boa legislaçáo? Acompanhando a sua linha de pensamento, testemunhamos que, nos capítulos subsequentes, nos quais ele define a lei e a tarefa do legislador, no Contrato social, instaura-se uma discussão acerca dos fatores que devem orientar o legislador. Lê-se, no início do capítulo VIII, do Livro segundo, que o legislador deve, antes de tudo, analisar se o povo ao qual ele se direciona

\footnotetext{
${ }^{40}$ Ao utilizar a palavra "milagre", no que diz respeito à grandeza de alma do legislador, esta se configura como mais um recurso do léxico rousseauísta, visto o autor do Contrato não crer em milagres, mas indica com esse termo figurativo atestar a raridade que é a presença de um verdadeiro legislador. Um fenômeno que, de tão excepcional sabedoria, tal homem seja capaz de falar a língua dos deuses e persuadir sem convencer. A persuasão dos indivíduos, bem como o empenho em recomendar leis medulares, contribuirá frontalmente para que os indivíduos convertidos em cidadáos sejam capazes de agir como partícipes do corpo soberano, a saber, se tornarem cidadãos virtuosos que amam a pátria, cultivam os costumes simples e julgam com liberdade e consciência. Portanto, a presença do legislador na ocasiāo da fundação do Estado será indispensável.

${ }^{41}$ Le vrai miracle qui doit prouver sa mission. (CS, II, VII. OCR3, tradução nossa).

${ }^{42}$ Tais como, escreve Rousseau, firmar normas em tábuas de pedra, utilizar oráculos, dissimular relaçôes secretas com possíveis divindades etc.
} 
tem capacidade de receber uma constituição salutar firmada na igualdade e na liberdade. Essa análise preambular assim se justifica, conforme declara Rousseau (1964, p. 385):

Os povos, assim como os homens, só são dóceis na juventude; envelhecendo, tornam-se incorrigíveis. Desde que se estabelecem os costumes e se enraízam os preconceitos, constitui empresa vá, querer reformá-los. ${ }^{43}$

Ainda no mesmo capítulo, de modo categórico e fatalista, Rousseau escreve que os povos podem granjear a liberdade, porém, uma vez perdida, jamais a reconquistarão. Defende também sobre o tempo de cada nação, que se assemelha ao dos homens, isto é, percorrem três etapas: a infância, a juventude e a maturidade. Prossegue, expressando sua predileçáo pelos Estados de territórios pequenos ${ }^{44}$, ao serem comparados aos grandes. Alega sua preferência baseada na concepção de que é custoso administrar um Estado de longas extensôes, em decorrência das grandes distâncias e de sua tendência a ir onerando o povo, conforme vai multiplicando suas províncias e distritos. Segundo Rousseau, uma constituição composta por leis apropriadas e vigorosas é o primeiro objetivo que o povo deve perseguir e, além disso, é de fulcral importância para um povo se apoiar na força que emana de um governo consistente.

Preconizando sua tese de que a política demográfica deve balizar a política econômica, o filósofo genebrino explana sobre como a dimensão territorial e o número de habitantes de um Estado serve de critérios para medir ${ }^{45}$ o corpo político e sustenta que a agricultura torna os povos fortes e independentes, ao contrário daqueles que dependem exclusivamente do comércio. Indicados tais aspectos e os critérios que o legislador deve ter em vista, procura então confrontar a questão em torno de qual povo tem condições de obter uma legislação saudável. Para Rousseau (1964, p. 390), este é o povo apropriado para adquirir uma legislação:

\footnotetext{
${ }^{43}$ Les peuples ainsi que les hommes ne sont dociles que dans leur jeunesse, ils deviennent incorrigibles en vieillissant ; quand une fois les coutumes sont établies et les préjugés enracinés, c'est une entreprise dangereuse et vaine de vouloir les réformer. (CS, II, VIII. OCR3, tradução nossa).

${ }^{44}$ No que tange à dimensão dos territórios, pode-se considerar que Rousseau está em sintonia com Aristóteles e Montesquieu.

${ }^{45} \mathrm{Na}$ percepção de Rousseau, existe entre uma e outra medida um liame útil para conferir ao Estado uma grandeza irrefutável. Se os homens formam o Estado e a terra os nutre, para que o liame solidifique a união, bastará que a terra conserve os habitantes e que o número de habitantes corresponda à quantidade de pessoas que a terra pode nutrir.
} 
Encontrando-se já ligado por qualquer laço de origem, interesse ou convenção, ainda não sofreu o verdadeiro jugo das leis; que não tem nem costumes nem superstiçốes muito arraigadas; que náo teme ser arrasado por uma invasão súbita; que, sem imiscuir-se nas brigas entre seus vizinhos, pode resistir sozinho a cada um deles, ou ligar-se a um para expulsar o outro; aquele de que cada membro pode ser conhecido por todos e no qual náo se está de modo algum forçado a sobrecarregar um homem com um fardo mais pesado do que possa suportar; o que pode viver sem os outros povos e que qualquer outro povo pode dispensar; o que não é nem rico nem pobre e pode bastar-se a si mesmo; enfim, aquele que une à consistência de um povo antigo, a docilidade de um povo novo. ${ }^{46}$

Diante dessas condiçóes, assaz difíceis de serem encontradas no mesmo povo, Jean-Jacques salienta - expressando certo ceticismo - que o estabelecimento de uma legislação edificante se torna um desafio complexo e o seu êxito da mesma forma, posto que é uma façanha incomum deparar-se com a simplicidade da natureza, dando conta de suprir os desprovimentos da sociedade. É um fenômeno raro ver as condiçôes elencadas amalgamadas em um único povo, por isso, muito fortuitamente encontramos constituições políticas ordenadas de maneira robusta. Embora Rousseau revele, em tom incrédulo, a existência de povos que ainda podem adquirir uma legislação saudável, ele nos surpreende, no final do capítulo X do Segundo livro do Contrato, ao afirmar que ainda havia na Europa um povo com condiçóes de receber uma legislação: trata-se da ilha da Córsega ${ }^{47}$, e a maior justificativa para

\footnotetext{
${ }^{46}[\ldots]$ se trouvant déjà lié par quelque union d'origine, d'intérêt ou de convention, n'a point encore porté le vrai joug des loix; celui qui n’a ni coutumes ni superstitions bien enracinées; celui qui ne craint pas d'être accablé par une invasion subite, qui, sans entrer dans les querelles de ses voisins, peut résister seul à chacun d'eux, ou s'aider de l'un pour repousser l'autre; celui dont chaque membre peut être connu de tous, et où l'on n'est point force de charger un homme d'um plus grand fardeau qu'un homme ne peut porter; celui qui peut se passer des autres peuples et dont tout autre peuple se passer; celui qui n'est ni riche ni pauvre et peut se suffire à lui-même; enfin celui qui réunit la consistance d'un ancien peuple avec la docilité d'un peuple nouveau (CS, II, X. OCR3, tradução nossa.)

${ }^{47}$ Em nota de rodapé da edição brasileira do Contrato social, ediçấo Os Pensadores, Lourival Gomes Machado sustenta que foi certamente o trecho referido do Contrato que estimulou Buttafuoco, mediante o consentimento de Paoli, a deflagrar relaçóes epistolares com Rousseau e convidá-lo a redigir um projeto de constituição para a Córsega. Uma espécie de passagem da teoria política rousseauniana à prática (tema consistentemente desenvolvido por Salinas Fortes). Essa oportunidade permitiu ao filósofo genebrino desempenhar a incumbência mais elevada a um homem, ou seja, a da funçáo de legislador. Não vamos nos deter aqui nos pormenores do projeto constitucional elaborado por Rousseau à Córsega, pois adotar essa postura representaria um desvio do nosso foco principal.
} 
isso é a forma com que severamente o seu povo vem lutando para salvaguardar a liberdade que reconquistou ${ }^{48}$.

Atesta-se, pela justificativa rousseauniana, que a liberdade se inscreve como um critério indispensável para que um povo receba um sistema de legislação. Ponderando sobre o lugar central da liberdade na démarche republicana promovida pelo autor genebrino e a ênfase conferida por ele a esse fundamento, no que concerne à Córsega, convém indagarmos: se não havia, além da Córsega, um "povo" apto a receber uma boa legislação, a função do legislador poderá ser plenamente realizada? Com o intuito de analisar essa questão, podemos avançar na nossa reflexáo, afirmando inicialmente que, sob a pena de Rousseau, todo sistema de legislação deve ter dois objetivos cardinais: "a liberdade e a igualdade". A liberdade, concebida como a não dependência a outrem, a participação direta na vida pública e o respeito à lei, uma vez que a lei enuncia a vontade do cidadão que é a vontade geral, e a igualdade, porque não é possível que a liberdade sobreviva sem ela. A igualdade não pode ser compreendida como níveis similares de poder e de riqueza. Todavia, em relação ao poder, é necessário frisar que o seu exercício deve ser desempenhado e amparado sempre considerando as leis e, no que tange à riqueza, declara Rousseau (1964, p. 391/392),

[...] que nenhum cidadão seja suficientemente opulento para poder comprar um outro e não haja nenhum tão pobre que se veja constrangido a vender-se: o que supóe, nos grandes, moderaçáo de bens e de crédito e, nos pequenos, moderação da avareza e da cupidez. ${ }^{49}$

Estabelecidos tais objetivos, os quais devem ser o alvo visado por toda constituição que se pretende saudável, é interessante sublinhar - a fim de confrontar a indagação que apresentamos -, que, no Capítulo XI do Segundo livro do Contrato, no qual o cidadão de Genebra perscruta os "vários sistemas de legislação", lê-se, logo em seguida, a fixação dos referidos objetivos, os quais devem ser adaptados a cada país, em conformidade com as especificidades da região e dos seus habitantes. Por conseguinte, deduz-se que a cada povo cabe uma legislaçáo singular, e não necessariamente ela precisa erigir a melhor constituição política entre as constituições, porém, precisa ser a melhor

\footnotetext{
${ }^{48}$ Esse trecho exemplifica claramente que a figura do legislador estabelece uma ponte entre o âmbito do dever ser e do programa político.

${ }^{49}$ Que nul citoyen ne soit assez opulent pour en pouvoir acheter un autre, et nui assez pauvre pour être contraint de se vendre; ce qui suppose du côté des grands modération d'avarice et de convoitise. (CS, II, XI. OCR3, traduçăo nossa).
} 
possível para o povo a que ela se destina. Isso significa que mesmo Rousseau comprovando as melhores condiçóes na Córsega para o recebimento de uma legislação saudável, em seu ponto de vista, “[...] cada povo reúne em si alguma coisa que o dirige de modo todo especial e torna sua legislação adequada somente a si mesmo" (ROUSSEAU, 1964, p. 393) ${ }^{50}$. Portanto, para que o legislador consiga desempenhar seu ofício de maneira plena, ele deverá avaliar prematuramente as peculiaridades do povo ao qual se dirige e elaborar seu conjunto de leis, considerando firmemente os objetivos a serem alcançados por intermédio da legislação.

A partir dessa forma, a legislação contribuirá para ordenar da melhor maneira possível a república e legitimar a relaçáo dos cidadãos com ela. Rousseau (1964, p. 393) sugere que, se um povo obtém boas leis, deve se empenhar em preservá-las, mas, independente das leis serem boas ou más, o "povo é sempre senhor de mudar suas leis" ${ }^{2}$. Isto é, ainda que o povo seja jovem e inábil para produzir um sistema de leis a si mesmo e realizar aquilo que o bem público demanda, ele terá a completa autonomia de modificar as leis recomendadas pelo legislador. Sem dúvida, se o legislador relevar as particularidades do povo ao qual a legislação se encaminha e demarcar claramente os objetivos do sistema de leis que apresentará, ele conseguirá realizar sua função com maestria.

Contudo, para além das leis políticas, das leis civis e das leis criminais que constituirão partes da legislação oferecida pelo legislador a um povo, a função republicana precípua do legislador será - mediante a produção de uma quarta espécie de lei, a que se insere como a mais valiosa e importante entre elas, aquela que se imprime no coração dos cidadãos, se reaviva e se fortifica cotidianamente, pelos usos e costumes - a de "transformar a natureza humana" forjando um espírito público em cada individuo perfeito e solitário e parte de um todo maior, ou seja: a função primeira do legislador será a de impulsionar o surgimento de uma consciência coletiva em cada cidadáo membro de uma ordem republicana, fazendo com que, assim, a sua conduta se torne compatível com as necessidades e exigências da vida em comum.

\footnotetext{
${ }^{50}$ Chaque peuple renferme en lui quelque cause qui les ordonne d'une maniere particuliere et rend as législation propre à lui seul. (CS, II, XI, OCR3, tradução nossa).

${ }^{51}$ Peuple est toujours le maitre de changer ses loix. (CS, II, XII, OCR3, tradução nossa).
} 


\section{CONSIDERAÇÓES FINAIS}

Tendo em vista a análise que realizamos sobre a função medular do legislador, na fundação da república, da mesma forma que se analisou a relevância peremptória de uma legislação salutar para a sustentação da espinha dorsal da ordem política, cabe categoricamente interrogar: o empenho do legislador para formar cidadãos dotados de espírito público é suficiente para assegurar a longevidade da ordenação republicana?

Para confrontar essa questão, é necessário, preliminarmente, rememorar alguns aspectos que confirmam a hipótese que foi estabelecida no início desta investigação, isto é, a de que "mais do que alguém hábil em apresentar leis para um determinado povo, a função republicana imprescindível endereçada ao legislador é a de contribuir para produzir um espírito público em cada cidadão pertencente à república”.

Reportemos algumas etapas da odisseia teórica percorrida e pontos cruciais de que nos valemos, a fim de comprovar a hipótese especificada. Na primeira etapa, quando abordamos a "necessidade de um Legislador", foi demonstrado que essa "necessidade" nasce da incapacidade do povo, recém-constituído, em desempenhar a intricada tarefa de elaborar um sistema de legislação para si próprio. Afinal, trata-se de um povo imaturo, que ainda baliza suas açóes de acordo com seus interesses mais urgentes. Por conta disso, necessita de um legislador. Nessa etapa do percurso efetuado, também assinalamos que o encargo do legislador se diferencia das incumbências do governo e do magistrado, e ele não tem poder de soberania, já que, na constelação das noções teóricas rousseauístas, a soberania compete tấo somente ao povo. Procurou-se igualmente salientar que o legislador é alguém capaz de alavancar o desenvolvimento das capacidades indispensáveis para a vida em comum.

$\mathrm{Na}$ segunda etapa, examinaram-se algumas peculiaridades em torno da figura do legislador e de sua "função republicana". Em outros termos, nesse exame, avaliaram-se as razóes pelas quais o legislador é considerado um homem excepcional na república e depara-se com algumas dificuldades, no cumprimento de sua faina. Esclarecemos simultaneamente o que realmente significa dizer que o legislador tem a habilidade de "transformar a natureza humana”. Utilizamos tal pressuposto, explicitando que em seu cerne se encontra a ideia de "socialização", concepção-chave para se compreender o legislador como uma peça fundamental na engrenagem republicana, pois, ao operar o processo de socializaçáo nos indivíduos (metamorfoseando 
indivíduos solitários em integrantes de um corpo coletivo), estará subsidiando diretamente a formação de um "espírito público" nos cidadãos da república.

$\mathrm{Na}$ terceira etapa, como uma espécie de desdobramento a partir da reflexão sobre a função republicana do legislador, operou-se uma perscrutação a respeito das "condiçóes para um povo receber uma boa legislação". Viram-se, nesse momento, quais elementos devem ser considerados pelo legislador em casos específicos, e tomamos a experiência de Rousseau com a Ilha da Córsega como parâmetro, a saber, o projeto de constituição elaborado pelo genebrino e apresentado àquela Ilha e que nos possibilita entender a passagem do plano teórico para o âmbito da prática. Assim, constatou-se a defesa rousseauniana de que a política demográfica deve servir de base para a política econômica; sublinhamos também a apologia de Rousseau concernente à agricultura como meio de tornar os povos vigorosos e independentes e lançamos luzes sobre sua ênfase: a de que uma legislação saudável deve conferir primazia e se esforçar em assegurar a igualdade e a liberdade. Além disso, certificou-se de que um sistema de legislação, para ser aplicado e se tornar viável, deve considerar os usos e costumes de um povo, da mesma forma que as particularidades da regiáo e dos seus nativos.

Retomados abreviadamente alguns pontos que contribuíram para sustentar a hipótese que estruturou a nossa investigaçáo, cumpre doravante, e como forma de desfecho, recapitular a questão inicial desta conclusão, isto é: "o empenho do legislador para formar cidadãos dotados de espírito público é suficiente para proporcionar a longevidade da ordenação republicana?” À primeira vista, presume-se que a filosofia rousseauísta apresenta uma resposta negativa a tal interrogação. Partindo dessa dedutiva inferência, podemos afirmar que a produção de um espírito público em cada cidadão por si só é insuficiente para garantir a longevidade da ordenaçáo política. Isso significa que, embora seja decisiva, na engrenagem política, a conservação da república, além da criação de um espírito público nos cidadãos, mediante a destreza do legislador, em longo prazo, há também outros pré-requisitos que devem somar forças juntamente à legislação para conquistar a durabilidade almejada. Quais seriam esses pré-requisitos?

Supôe-se que sejam basicamente dois - o primeiro: instituições ${ }^{52}$ políticas republicanas robustas e capazes de contribuir para preservar a soberania popular e a liberdade dos cidadáos, destarte como a da república,

52 Tais como as elencadas por Rousseau, no livro IV do Contrato, isto é, o Tribunato, a Ditadura, a Censura e a Religiăo civil. 
quando em divergência a prováveis golpes disparados por pessoas ou grupos munidos de seus interesses particulares contra a vontade geral; o segundo prérequisito: cidadãos dotados de virtude cívica, ou seja, que amem a pátria, pois assim serão capazes de defender a ordem republicana e a liberdade.

Conclui-se que, mesmo com o esforço do legislador em impelir o advento de um espírito público nos cidadãos, recurso que se tornará fundamental para a manutenção da república, não basta à ordem política ter cidadãos comprometidos com o bem público, embora a fabricação do aludido “espírito" seja indispensável. É necessário um conjunto de mecanismos que atuem paralelamente, com o objetivo de criar condiçóes adequadas para garantir a estabilidade da ordenação republicana. Quiçá, em vista disso, por um lado, Rousseau sublinhe, no Tratado sobre a economia politica, no Contrato e nos seus escritos de cunho prático - Projeto de constituição para a Córsega e Consideraçóes sobre o governo da Polônia -, a imprescindibilidade de uma educação pública que propicie a criação da noção de virtude cívica nos cidadãos, desde uma tenra idade. E, por outro, apresente pormenorizadamente algumas instituiçôes políticas no livro IV do Contrato que, mesmo tendo suas singularidades e atuações específicas, se inscrevem como ferramentas viáveis para garantir a durabilidade do regime republicano.

ALVES, V. F. C. The legislator and the formation of the public spirit in the republicanism of Rousseau. Trans/form/ação, Marília, v. 43, n. 2, p. 301-324, Abr./Jun., 2020.

ABSTRACT: In closing his explanation concerning the notion of law, in chapter VI of the second book of the Social contract, Jean-Jacques Rousseau has some concerns about the ability of a premature population to develop a legislation system. Such concerns lead the Genevan thinker to advocate the need for a controversial and exceptional personage in the republican political machinery: The legislator. Considering the exceptionality of this personage, this article will support the hypothesis that, more than being one skilled at presenting a set of laws to a particular people, the primary republican function assigned to the legislator is to contribute to engender a public spirit in every citizen belonging to the republic. The hypothesis presented will be defended from three objectives: first, I shall examine the reasons why Rousseau deems it necessary to have a legislator in the republican order; Second, I shall analyze why the construction of a public spirit by the legislator may be considered a republican function; third, I shall look into the conditions necessary for a people to receive a good legislation.

KeYwords: Legislator. Public spirit. Republicanism. Rousseau. 


\section{REFERÊNCIAS}

ARISTÓTELES. A política. São Paulo: Martins Fontes, 2002.

BURGELIN, M. Annales. Le coloque Rousseau au Collège de France. Paris: Armand Colin, 1963.

CASSIRER, Ernest. A questáo Jean-Jacques Rousseau. São Paulo: Unesp, 1999.

DERATHÉ, Robert. L'Homme selon Rousseau. Études sur le Contrat social de JeanJacques Rousseau: Actes des journées d'études organisées à Dijon pour la commémoration du 200e aniversaire du Contrat social. Dijon: p. 388-428, 1964.

GAGNEBIN, M. Le role du législateur dans les conceptions politiques de Rousseau. Études sur le "Contrat social" de J.-J. Rousseau. Actes des journées d'études tênues à Dijon, p. 277-290, 1962.

MAQUIAVEL, N. Discurso sobre a primeira década de Tito Lívio. São Paulo: Martins Fontes, 2007.

MARTIN-HAAG, Éliane. Rousseau ou la conscience sociale des Lumières. Paris: Honoré Champio, 2009.

MASTERS, Roger D. The political philosophy of Rousseau. Princeton: University Press, New Jersey, 1968.

MONTESQUIEU. Consideraçóes sobre as causas da grandeza dos romanos e da sua decadência. São Paulo: Saraiva, 2005.

MONTESQUIEU. O espírito das leis. São Paulo: Nova Cultural, 1997 (Coleção Os Pensadores).

NASCIMENTO, Milton Meira. O legislador e o escritor político, duas formas e aproximaçáo da opiniáo pública em Rousseau. Belo Horizonte: Kriterion, Ed. UFMG, 1997.

MONTESQUIEU. Contrato social: entre a escala e o programa. São Paulo: Discurso, Ed. USP, 1984.

PLATÃO. A república. São Paulo: Nova Cultural, 1997 (Coleção Os Pensadores).

PLATÃO. As leis. São Paulo: Edipro, 2010.

PLATÃO. Político. São Paulo: Abril Cultural, 1972. (Coleção Os Pensadores).

POLIN, R. La fonction du législateur chez J.-J. Rousseau. In POLIN, R. Jean-Jacques Rousseau et son Oeuvre. Problèmes et Recherches, Paris, Klincksieck, 1964.

ROUSSEAU, J.-J. Oeuvres complètes. Paris: Gallimard, Volumes I, II, III et IV - 1959, 1961, 1964, 1969. (Bibliothèque de La Pléiade) 
ROUSSEAU, J.-J. Do Contrato Social. Tradução de Lourdes Santos Machado; Introdução e notas de Paul Arbousse-Bastide e Lourival Gomes Machado São Paulo: Nova Cultural, 1997 (Coleção Os Pensadores).

ROUSSEAU, J.-J. Rousseau e as relaçóes internacionais. São Paulo: Imprensa Oficial do Estado e Editora UnB, 2003.

SALINAS FORTES, Luís Roberto. Rousseau: da teoria à prática. São Paulo: Ática, 1976.

SHKLAR, J. N. Men \& citizens - a study of Rousseau's social theory. Cambridge University Press: New Yourk: 1985.

SPECTOR, Céline. Rousseau: les paradoxes de l'autonomie démocratique. Paris: Michalon Éditeur, 2015.

STRAUSS, Leo. L'intention de Rousseau. In: STRAUSS, Leo. Pensée de Rousseau. Paris: Seuil, p. 67-94, 1984.

VAUGHAN, C.E. The political writings of Jean-Jacques Rousseau. Editado consoante os manuscritos originais e as ediçóes autênticas, com Introduçóes e Notas, Cambridge University Press, 2 v., in- $8^{\circ}, 1915$

Recebido: 11/12/2017

Aceito: 26/4/2019 
ALVES, V. F. C. 